\title{
Renewable energy sources in the Region of Warmia and Mazury in north-eastern Poland
}

\author{
Janusz Piechocki ${ }^{1}$, Maciej Neugebauer ${ }^{1}$, Joanna Hałacz ${ }^{1}$, Aneta Skotnicka-Siepsiak ${ }^{2}$, \\ Andrzej Lange ${ }^{1}$ \\ ${ }^{1}$ University of Warmia and Mazury in Olsztyn / Faculty of Technical Sciences / Department of \\ Electrical, Power, Electronic and Control Engineering, Poland \\ ${ }^{2}$ University of Warmia and Mazury in Olsztyn / Faculty of Geodesy, Geospatial and Civil \\ Engineering / Institute of Building Engineering, Poland
}

\begin{abstract}
The region of Warmia and Mazury in Poland is fourth largest voivodeship which occupies $7,7 \%$ of the country's territory. The Region of Warmia and Mazury in north-eastern Poland is situated at a distance from conventional energy sources. Therefore, the Region is a Polish leader in power generation from renewable energy sources. The structure of electrical grids in the Region of Warmia and Mazury is poorly developed and insufficient. Therefore, electric power infrastructure should be expanded and modernized as part of energy sector development to increase energy efficiency as well as electricity and heat production from renewable energy sources. The Region of Warmia and Mazury is characterized by a considerable discrepancy between energy generation and energy use. It recent years, electricity consumption exceeded energy production more than 10 -fold. The region has to purchase energy from external sources and develop new generation methods, in particular those that rely on renewable resources of energy. In Warmia and Mazury, the most popular renewable energy sources include biomass, wind turbines, solar and photovoltaic panels, hydropower, heat pumps and geothermal energy. The region is characterized by distributed energy generation in small polants that carter mostly to local needs. The University of Warmia and Mazury in Olsztyn has developed, in collaboration with the Warmia and Mazury Energy Agency, a renewable energy strategy for 2010-2020 in the Region of Warmia and Mazury. The strategy is consistent with the Polish Energy Policy and the national plan for the use of renewable energy sources. In the region Warmia and Mazury, efforts are being made to generate $14,000 \mathrm{TJ}$ of energy from renewable sources ( approx. 18,4\% of energy consumption in the region) and 1,700 GWh of electricity (approx. $49 \%$ of energy consumption in the region), reduce $\mathrm{CO} 2$ emissions in the energy sector by $1,530,000$ tons, and the decrease energy consumption per unit of GDP (PLN 1 million) from $1.94 \mathrm{TJ}$ to $1.67 \mathrm{TJ}$ by 2020.
\end{abstract}

\section{Introduction}

State energy policy is one of the most important public tasks carried out by the central government. Energy security promotes the growth of other branches of the economy; 
therefore, decisions regarding the supply of energy carriers play a vital role in every country. The energy policy agenda and the circumstances under which these policies are implemented are influenced by the EU strategies and national legislation. Policy documents at the central, regional and local level should be cohesive. In the light of the EU's " $3 \times 20$ " energy and climate package which constitutes the backbone of Europe's energy policy, every Member State has to develop binding legislation to ensure that the EU meets its climate and energy targets for 2020.

A country's energy needs, calculated based on its energy balance, should be satisfied with the involvement of local energy carriers and, most importantly, renewable energy sources and the rational use of conventional sources of energy [3,5].

The Region of Warmia and Mazury in north-eastern Poland is situated at a considerable distance from conventional energy sources. Less than $10 \%$ of the energy consumed in Warmia and Mazury is produced locally, and the remaining energy is purchased from other Polish regions, which accelerates their growth. The main goals of the region's energy strategy should be to increase its energy efficiency, expand and upgrade its energy infrastructure and the increase the generation of electricity and heat from renewable sources.

For this reason, the region is a Polish leader in power generation from renewable energy sources.

The University of Warmia and Mazury in Olsztyn and the Warmia and Mazury Energy Agency have developed a renewable energy strategy for 2010-2020 in the Region of Warmia and Mazury.

The strategy is consistent with the Polish Energy Policy and the national action plan for the use of renewable energy sources. The strategy has been developed based on the results of studies investigating the use of heat pumps in 2000-2010 [1,6].

\section{General description of the Warmia and Mazury region}

The region of Warmia and Mazury in Poland is fourth largest voivodeship which occupies $7,7 \%$ of the country's territory. Warmia and Mazury is the least densely populated Polish region, which directly affects its energy demand. The region is situated far from industrial areas and it is characterized by a clean natural environment that has been minimally transformed by human activity. The main sources of income are tourism and agriculture and the region is deficient in technical infrastructure.

The power grid in the region of Warmia and Mazury is poorly developed and does not meet the local demand. The number of power transmission lines is insufficient and the existing lines are overloaded and require overhaul. The absence of secure and high-quality energy supplies discourages investment in the region. The key targets for the development of the energy sector in the region should be to improve energy efficiency, increase energy and heat generation from renewable sources and to expand and modernize electrical power infrastructure.

Warmia and Mazury is characterized by a considerable discrepancy between energy generation and energy use. In recent years, electricity consumption exceeded energy production more than 10 -fold. The region has to purchase energy from external sources and develop new generation methods, in particular those that on renewable resources of energy.

\section{Current status of renewable energy sources in Warmia and Mazury region}

The most popular renewable energy sources in the Region of Warmia and Mazury are: 
-Biomass;

-Wind energy;

-Solar energy:

-as solar collectors,

-as photovoltaic panels;

-Hydropower;

- Heat pumps;

- Geothermal energy.

Warmia and Mazury is Poland is also one of the least populated Polish regions. Low population density influences the region's energy needs. The region is characterized by unspoiled nature and an abundance of forests, and most incomes are derived from agriculture and tourism. Warmia and Mazury is located far from the major centers of industrial activity, and it is deficient in modern technical infrastructure.

The energy grid in the analyzed region is weakly developed and does not fully cater to local needs. Power transmission lines are overloaded and many of them are in dire need of upgrading. Low energy security is the main reason for the region's inability to attract investors. In addition to improving energy efficiency and increasing the share of renewables in electricity and heat generation, one of the main goals of the region's energy strategy should be to expand and upgrade its energy infrastructure $[2,4]$.

Warmia and Mazury is characterized by a considerable discrepancy between energy production and energy consumption. Most energy has to be purchased from other regions, which prevents Warmia and Mazury from fully harnessing its economic potential. To compensate for these deficiencies, the region should develop new energy generation methods, in particular by increasing the share electricity produced from renewable sources.

This solution will not only cut energy-related expenditures, but it will also create new jobs and increase the region's energy security. Warmia and Mazury ranks 14th in Poland in terms of energy consumption. The low demand for energy is undoubtedly associated with low levels of industrialization in the region.

\section{SWOT analysis of the renewable energy sector in the Warmia and Mazury region}

\subsection{Strengths}

High potential of local renewable energy sources;

Availability of labor in rural areas;

Presence of a large university;

Presence of a large Agricultural Advisory Center;

Presence of the Energy Agency of the Region of Warmia and Mazury;

Favorable climate.

\subsection{Weaknesses:}

A large part of the region receives protection under the NATURA 2000 program and other conservation measures;

Absence of regional strategic documents targeting renewable energy sources;

Low levels of social awareness and lack of acceptance for renewable energy technologies;

Limited options for connecting new energy producers to the power grid;

The power grid requires upgrading; 
Poorly developed gas network;

Long and complex procedure of connecting small-scale renewable energy installations to the power grid;

Low levels of education on renewable energy;

Shortage of energy experts in local governments;

Most municipalities do not have plans for future energy supply;

Energy distributors and consumers have little interest in renewable energy sources.

\subsection{Opportunities}

Development of the local market-production of equipment and biomass processing;

Improved energy security through diversification and decentralization of energy generation;

Reduced losses in energy transmission between regions;

Reduced greenhouse gas and dust emissions;

Improvement in power grid parameters;

Information, educational and promotional campaigns raise public awareness about renewable energy sources;

New avenues in agricultural production;

Higher employment in rural areas;

Greater focus on energy management and energy efficiency in the local administration;

Reduced demand for fossil fuels;

High availability of European Union funds for renewable energy generation;

\subsection{Threats}

Frequent legislative changes;

Low levels of public awareness about renewable energy technologies;

Strong pressure from fossil industry lobbyists;

Biomass co-firing exerts a negative impact on the local biomass market.

\section{Conclusions}

Generation of electricity from renewable energy sources in Warmia and Mazury region in 2015:

-Total generation of electricity from renewable energy sources: $969829 \mathrm{MWh}$

-Total consumption of electricity in this region: $3816580 \mathrm{MWh}$

-Share of electricity from renewable energy sources in total consumption: $25,41 \%$

Renewable energy systems in Warmia and Mazury region as of 31 December 2018:

-Biogas plants: 15,302 MW

-Biomass-fired power plants: 26,044 MW

-Solar energy systems: 16,063 MW

-Wind energy systems: $351,865 \mathrm{MW}$

-Hydropower systems: 22,545 MW

Renewable energy targets in Warmia and Mazury region until 2020:

-Generation of 14,000 TJ of energy from renewable sources, i.e. around 18,4\% of total energy consumption in region

-Generation of $1,700 \mathrm{GWh}$ of electricity from renewable sources, i.e. around $49 \%$ of total electricity consumption in region 
-Reduction of $\mathrm{CO}_{2}$ emissions in the energy sector by 1,530,000 tons on the assumption that $1 \mathrm{kWh}$ of electricity generated from renewable decreases emissions by $0,9 \mathrm{~kg}$ $\mathrm{CO}_{2}$

-Reduction of energy consumption per unit of GDP (PLN 1 million) from 1.94 TJ to $1.67 \mathrm{TJ}$

The results of the analyses investigating the development of renewable energy sources in the Region of Warmia and Mazury and the conclusions formulated in the relevant policy papers should constitute a basis for planning regional goals in the area of renewable energy generation in the strategy for the socioeconomic development of the Region of Warmia and Mazury until 2025.

The relevant measures have to be undertaken in view of the EU's multiannual financial framework. In the future, grants and subsidies offered by development programs will be awarded only to regions which have implemented sectoral policies in their socioeconomic development strategies. The above implies that the goals of every sectoral policy have to be clearly defined.

Local governments which fail to implement programs supporting the achievement of energy policy goals will have limited access to funding for regional investments in the area of energy and environmental protection.

The Region of Warmia and Mazury produces less than $10 \%$ of the consumed energy and imports the remainder from other Polish regions. For this reason, the main goals of the region's energy policy should be to improve the efficiency of the existing power grids, modernize and build new energy infrastructure and increase the share of renewable power sources.

\section{References}

1. Brzozowska R., Neugebauer M., Piechocki J., Lakes as a heat source for heat pumps a model study to determine the ecological impact of summer heat transfer. Geothermal, Wind and Solar Energy Applications in Agriculture and Aquaculture / Editors: J. Bundschuh, G. Chen, D. Chandrasekharam, J. Piechocki. CRC Press Taylor \& Francis Group (2017).

2. Lewandowski W. M., Proekologiczne źródła energii odnawialnej. Wydawnictwo Naukowo-Techniczne, Warszawa (2001).

3. Neugebauer M., Sołowiej P., Piechocki J., Czekała W., Janczak D., The influence of the $\mathrm{C}: \mathrm{N}$ ratio on the composting rate. International Journal of Smart Grid and Clean Energy (2017).

4. Piechocki J., Sołowiej P., Neugebauer M., Zasoby odnawialnych źródeł energii i ich wykorzystanie na terenie województwa warmińsko-mazurskiego. Konferencja Naukowa: Inżynieria Rolnicza - Nauka i Praktyka, WNT UWM (2016).

5. Piechocki J., Sołowiej P., Neugebauer M., Nalepa K., Wesołowski M., The use of heat pumps for heating purposes in the Region of Warmia and Mazury in north-eastern Poland. $5^{\text {th }}$ International Conference on Renewable Energy Sources, Krynica Zdrój (2018).

6. Skotnicka-Siepsiak A., Wesołowski M, Piechocki J., Experimental and numerical study of an earth-to-air heat exchanger in north-eastern Poland. Polish Journal of Environmental Studies (3). (2018). 